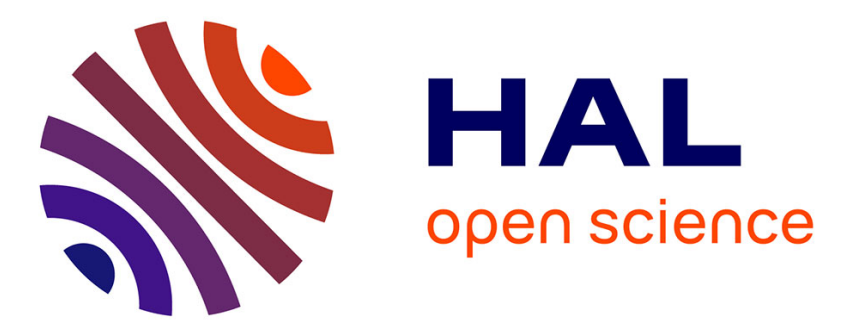

\title{
Concordance of clinical and molecular breast cancer subtyping in the context of preoperative chemotherapy response
}

\author{
Jorma J. Ronde, Juliane Hannemann, Hans Halfwerk, Lennart Mulder, \\ Marieke E. Straver, Marie-Jeanne T. F. D. Vrancken Peeters, Jelle Wesseling, \\ Marc Vijver, Lodewyk F. A. Wessels, Sjoerd Rodenhuis
}

\section{To cite this version:}

Jorma J. Ronde, Juliane Hannemann, Hans Halfwerk, Lennart Mulder, Marieke E. Straver, et al.. Concordance of clinical and molecular breast cancer subtyping in the context of preoperative chemotherapy response. Breast Cancer Research and Treatment, 2009, 119 (1), pp.119-126. 10.1007/s10549-0090499-6 . hal-00535389

\author{
HAL Id: hal-00535389 \\ https://hal.science/hal-00535389
}

Submitted on 11 Nov 2010

HAL is a multi-disciplinary open access archive for the deposit and dissemination of scientific research documents, whether they are published or not. The documents may come from teaching and research institutions in France or abroad, or from public or private research centers.
L'archive ouverte pluridisciplinaire HAL, est destinée au dépôt et à la diffusion de documents scientifiques de niveau recherche, publiés ou non, émanant des établissements d'enseignement et de recherche français ou étrangers, des laboratoires publics ou privés. 


\title{
Concordance of clinical and molecular breast cancer subtyping in the context of preoperative chemotherapy response
}

\author{
Jorma J. de Ronde · Juliane Hannemann · Hans Halfwerk · Lennart Mulder • \\ Marieke E. Straver - Marie-Jeanne T. F. D. Vrancken Peeters • \\ Jelle Wesseling · Marc van de Vijver · Lodewyk F. A. Wessels • \\ Sjoerd Rodenhuis
}

Received: 2 June 2009/Accepted: 25 July 2009/Published online: 8 August 2009

(C) Springer Science+Business Media, LLC. 2009

\begin{abstract}
ER, PR and HER2 status in breast cancer are important markers for the selection of drug therapy. By immunohistochemistry (IHC), three major breast cancer subtypes can be distinguished: Triple negative $\left(\mathrm{TN}_{\mathrm{IHC}}\right)$, HER $2+_{\mathrm{IHC}}$ and Luminal $_{\mathrm{IHC}}\left(\mathrm{ER}+_{\mathrm{IHC}} / \mathrm{HER} 2-_{\mathrm{IHC}}\right)$. By using the intrinsic gene set defined by $\mathrm{Hu}$ et al. five molecular subtypes (Basal ${ }_{\text {mRNA }}$, HER2 $+_{\text {mRNA }}$, Luminal $\mathrm{A}_{\text {mRNA }}$, Luminal $\mathrm{B}_{\mathrm{mRNA}}$ and Normal-like $\mathrm{mRNA}_{\text {a }}$ ) can be defined. We studied the concordance between analogous subtypes and their prediction of response to neoadjuvant chemotherapy. We classified 195 breast tumors by both IHC and mRNA expression analysis of patients who received neoadjuvant treatment at the Netherlands Cancer institute for Stage II-III breast cancer between 2000 and 2007. The pathological complete remission $(\mathrm{pCR})$ rate was used to
\end{abstract}

Electronic supplementary material The online version of this article (doi:10.1007/s10549-009-0499-6) contains supplementary material, which is available to authorized users.

J. J. de Ronde · L. F. A. Wessels

Department of Bioinformatics and Statistics, The Netherlands

Cancer Institute, Amsterdam, The Netherlands

e-mail: j.d.ronde@nki.nl

M. E. Straver - M.-J. T. F. D. Vrancken Peeters ·

S. Rodenhuis $(\bowtie)$

Department of Medical Oncology, The Netherlands Cancer Institute, Amsterdam, The Netherlands

e-mail: s.rodenhuis@nki.nl

J. J. de Ronde - J. Hannemann · H. Halfwerk - L. Mulder . J. Wesseling · M. van de Vijver

Department Experimental Therapy, The Netherlands Cancer Institute, Amsterdam, The Netherlands assess chemotherapy response. The IHC and molecular subtypes showed high concordance with the exception of the HER $2+_{\text {IHC }}$ group. $60 \%$ of the HER $2+_{\text {IHC }}$ tumors were not classified as HER $2+_{\text {mRNA }}$. The HER $2+_{\mathrm{IHC}} /$ Luminal A or $\mathrm{B}_{\text {mRNA }}$ group had a low response rate to a trastuzumabchemotherapy combination with a pCR rate of $8 \%$, while the HER $2+_{\text {mRNA }}$ group had a pCR rate of $54 \%$. The Luminal $\mathrm{A}_{\mathrm{mRNA}}$ and Luminal $\mathrm{B}_{\mathrm{mRNA}}$ groups showed similar degrees of response to chemotherapy. Neither the PR status nor the endocrine responsiveness index subdivided the $\mathrm{ER}+{ }_{\mathrm{IHC}}$ tumors accurately into Luminal $\mathrm{A}_{\mathrm{mRNA}}$ and Luminal $\mathrm{B}_{\mathrm{mRNA}}$ groups. Molecular subtyping suggests the existence of a HER $2+_{\mathrm{IHC}} /$ Luminal ${ }_{\text {mRNA }}$ group that responds poorly to trastuzumab-based chemotherapy. For Luminal ${ }_{\mathrm{IHC}}$ and triple negative $\mathrm{IHC}_{\mathrm{IHC}}$ tumors, further subdivision into molecular subgroups does not offer a clear advantage in treatment selection.

Keywords Breast cancer subtypes - Intrinsic genes Neoadjuvant chemotherapy response $\cdot$ Molecular subtypes $\cdot$ Clinical subtypes

\section{Introduction}

Breast cancer is a highly heterogeneous disease and the need for individualized therapy is widely accepted. In addition to clinical parameters such as tumor size and grade, lymph node involvement and patient demographics, several molecular markers are employed in routine patient care [1-3]. The most important ones include the estrogen receptor (ER), the progesterone receptor (PR) and the human epidermal growth factor receptor 2 (HER2). ERpositive tumors are thought to have characteristics of the luminal cell type and are frequently responsive to endocrine 
treatment (such as tamoxifen or aromatase inhibitors) $[4,5]$. ER-negative tumors are considered to be more similar to the basal cell type and do not respond to endocrine treatment. Tumors with a HER2 gene amplification may respond to targeted therapy, such as trastuzumab or lapatinib [6-8]. The PR is a prognostic marker, but the Oxford overview of adjuvant therapy does not support its ability to predict resistance to chemotherapy $(\mathrm{CT})$. It is sometimes stated that $\mathrm{ER}+{ }_{\mathrm{IHC}} / \mathrm{PR}+{ }_{\mathrm{IHC}}$ tumors coincide with the Luminal $\mathrm{A}_{\mathrm{mRNA}}$ breast cancer subtype [9].

The most standardized way of assessing the status of these biomarkers is immunohistochemistry (IHC). Using antibodies with specificity for each marker, the number of positively staining cells can be estimated by the pathologist from a section of the tumor. Although widely accepted and available, the technique is not perfect. The determination of HER2 protein expression status based on IHC is known to have a false-positive rate around $10 \%$, even in experienced laboratories [10, 11]. Many institutions also perform fluorescent or chromogenic in situ hybridization (FISH or CISH) to confirm HER2 gene amplification or to establish its presence or absence when IHC results are ambiguous. Since the choice of treatment critically depends on the HER2 gene amplification status, highly reliable analyses are essential [12]. Subtyping of breast cancer by IHC assays for ER, PR and IHC and in situ hybridization for HER2, yields three broad groups: Luminal ${ }_{\mathrm{IHC}}$, when ER is positive and HER2 is not amplified; HER $2+_{\mathrm{IHC}}$ tumors, which may be ER+ or ER-; and triple negative tumors $\left(\mathrm{TN}_{\mathrm{IHC}}\right)$ when ER, PR and HER2 are all negative $[13,14]$.

More recently, an mRNA expression-based subtyping of breast cancer, introduced by Perou et al. [15] has gained wide acceptance. These investigators identified an intrinsic gene set that distinguished five different molecular subtypes: Luminal $\mathrm{A}_{\mathrm{mRNA}}$, Luminal $\mathrm{B}_{\mathrm{mRNA}}$, HER2 $+_{\mathrm{mRNA}}$, Basal $_{\text {mRNA }}$ and Normal-like mRNA $_{\text {[15-17]. Several studies }}$ have shown that the Luminal $A_{\text {mRNA }}$ subtype is associated with a favorable prognosis, while the Basal $_{\text {mRNA }}$ subtype is prognostically unfavorable [16-18]. This raises the question of how well the two subtyping systems match and whether the molecular subtyping adds predictive power to the IHC subtyping in the neoadjuvant setting. To our knowledge, no such formal analysis has been performed. In this paper, we present the results of a comparative analysis on 195 patients.

\section{Patients and methods}

\section{Patients}

Biopsies of primary breast tumors were collected from 195 women who received neoadjuvant treatment at the
Netherlands Cancer Institute between 2000 and 2007. These patients took part in one of two ongoing clinical trials or received standard treatment. All patients eligible for preoperative chemotherapy were diagnosed with invasive breast cancer and either a tumor diameter of at least $3 \mathrm{~cm}$, lymph node involvement or both. Both trials were approved by the ethical committee and informed consent was obtained from all patients. Biopsies were taken using a core needle under ultrasound guidance. After collection, specimens were snap-frozen in liquid nitrogen and stored at $-70^{\circ} \mathrm{C}$.

Neoadjuvant chemotherapy for Luminal ${ }_{\mathrm{IHC}}$ and $\mathrm{TN}_{\mathrm{IHC}}$ tumors consisted of either dose-dense AC (doxorubicin and cyclophosphamide, standard arm) or docetaxel and capecitabine (experimental arm) for three courses. After evaluation, by comparing a repeat contrast-enhanced MRI to a prechemotherapy MRI, patients with favorably responding tumors continued their initial chemotherapy and patients with minimal response or stable disease were switched to the alternative chemotherapy regimen [19]. Most tumors harboring HER2 gene amplifications were treated with trastuzumab and weekly paclitaxel and carboplatin (37 of 43 tumors). The other six patients with HER2 + tumors, who started treatment before 2006, began treatment with dose-dense AC. Details of the studies will be published separately. For four patients, no response data were available and as a result the therapy response analysis was limited to 191 patients. An overview of patient and tumor characteristics is given in Table 1.

\section{Response evaluation}

The response to treatment at the time of surgery was taken as an end point. Both pathology and MRI findings were used for response evaluation. We included both the response of the primary tumor and the nodal status after treatment in our definition of pathological response.

Only patients with a complete absence of invasive tumor cells (irrespective of carcinoma in situ) in the surgical specimen of the breast (i.e., pCR of the primary tumor) and of the lymph nodes were considered to have a pCR. It has been shown that pCR correlates with outcome and that patients achieving a pCR by this definition have a very good prognosis [20-25]. The response of the primary tumor was categorized in additional categories as described in the following paragraphs.

When only a small number of scattered tumor cells were present at pathology examination, the response was classified as a 'near pCR' (npCR). Patients with primary tumor shrinkage of more than $50 \%$ but with residual tumor were considered partial responders (PR). And at last, patients with tumor shrinkage of less than $50 \%$ as evaluated by 
Table 1 Patient and tumor characteristics

\begin{tabular}{|c|c|}
\hline Characteristic & Number $(\%)$ \\
\hline Samples & 195 \\
\hline Samples included in analysis & 191 \\
\hline \multicolumn{2}{|l|}{ Age (years) } \\
\hline Mean & 46 \\
\hline Standard deviation & 9 \\
\hline \multicolumn{2}{|l|}{ ER } \\
\hline Positive & $127(66)$ \\
\hline Negative & $64(34)$ \\
\hline \multicolumn{2}{|l|}{ Node } \\
\hline Positive & $136(71)$ \\
\hline Negative & $51(27)$ \\
\hline Not evaluated & $4(2)$ \\
\hline \multicolumn{2}{|l|}{ HER2 gene amplification } \\
\hline Positive & $38(20)$ \\
\hline False positive & $5(3)$ \\
\hline Negative & $148(77)$ \\
\hline \multicolumn{2}{|l|}{ Tumor size $(\mathrm{cm})$} \\
\hline$\leq 2$ & $12(6)$ \\
\hline$>2$ & $179(94)$ \\
\hline \multicolumn{2}{|l|}{ Grade } \\
\hline Low & $3(1)$ \\
\hline Medium & $61(32)$ \\
\hline High & $57(30)$ \\
\hline Unknown $^{\mathrm{a}}$ & $70(37)$ \\
\hline \multicolumn{2}{|l|}{ IHC subtype } \\
\hline Triple negative & $47(25)$ \\
\hline HER2+ & $43(22)$ \\
\hline Luminal & $101(53)$ \\
\hline \multicolumn{2}{|l|}{ Molecular subtype } \\
\hline Basal & $52(27)$ \\
\hline HER2+ & $19(10)$ \\
\hline Luminal A & $83(43)$ \\
\hline Luminal B & $28(15)$ \\
\hline Normal-like & $9(5)$ \\
\hline \multicolumn{2}{|l|}{ Initial chemotherapy ${ }^{\mathrm{b}}$} \\
\hline $\mathrm{AC}$ & $132(69)$ \\
\hline $\mathrm{CD}$ & $24(13)$ \\
\hline PTC & $33(17)$ \\
\hline Other & $2(1)$ \\
\hline
\end{tabular}

${ }^{a}$ For a number of biopsies the grade could not be determined

b AC: doxorubicin and cyclophosphamide; CD: capecitabine and docetaxel; PTC: paclitaxel, trastuzumab and carboplatin; Other: fluorouracil, epirubicin and cyclophosphamide (FEC) or doxorubicin and docetaxel $(\mathrm{AD})$

MRI and pathological assessment were considered to be non-responders (NR). The MRIs were performed and interpreted as reported previously [19].
Immunohistochemistry

Paraffin-embedded sections were immunohistochemically assessed as described previously with the following exceptions [26]. ER and PR positivity was defined as at least $10 \%$ of cells staining positive for ER or PR, respectively. The IHC staining for HER2 was scored according to standard criteria as $0,1+, 2+$ or $3+$. Scores of 0 and $1+$ were considered negative and $3+$ was considered positive. When a score of $2+$ was found, additional CISH testing was done to establish HER2 gene amplification status. CISH testing was also done when the IHC score was $3+$ but no high HER2 expression was encountered in the mRNA expression microarray analysis. Tumors with at least five HER2 copies per nucleus, as detected by CISH, were considered HER2 + . The tumor grade was assessed using the Elston and Ellis method [27].

Molecular subtyping

mRNA isolation and extraction from the frozen material were performed as described previously [26]. A 5- $\mu \mathrm{m}$ section halfway through the biopsy was stained for hematoxylin and eosin and analyzed by a pathologist for tumor percentage. Only samples that contained at least 50\% tumor cells were subsequently analyzed on a microarray. The microarray analysis was performed as described previously, except no filtering of genes was done [26]. Briefly, all samples were hybridized in dye-swap to in-house printed $35 \mathrm{k}$ Operon microarrays using a reference pool of 100 invasive breast carcinomas. Background-corrected intensities were used to calculate $\log _{2}$ transformed ratios and the ratios were normalized using a lowess fit per subarray.

The subtype single sample predictor developed by $\mathrm{Hu}$ et al. [18.] was used to assign a molecular subtype to the samples based on their expression profiles across the intrinsic gene set. Briefly, we mapped the intrinsic genes to the Operon platform (Supplemental data file 1), when a single gene was represented by multiple probes the average of the corresponding probes was used. Subsequently, for all samples the Spearman correlation of a sample to the centroid of each corresponding molecular subtype was calculated. Each sample was then assigned to the subtype with the highest correlation coefficient.

\section{Endocrine responsiveness}

The endocrine responsiveness index (ERI) was defined as was described by Colleoni et al. [28]. Tumors were classified as highly endocrine responsive when ER and PR were positive in at least $50 \%$ of the cells, as incompletely endocrine responsive when either ER or PR was positive in 
less than $50 \%$ of the cells and as endocrine non-responsive when both ER and PR were negative in all cells.

\section{Statistical tests}

Concordance between IHC and molecular subtyping was assessed by the percentage of concordance and by the kappa test [29]. The Fisher exact test was used to assess the association between the different subtype groupings and the treatment response in terms of pCR. For the univariate and multivariate analyses, logistic regression was employed. The Cochran-Armitage exact test was used to determine trend effects. The Mann-Whitney test was used to assess PTEN mRNA expression differences between groups. All data analyses were performed using the $\mathrm{R}$ software package.

\section{Results}

Concordance of clinical and molecular subtypes

To assess the concordance of the subtypes, we (1) disre-

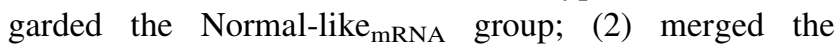
Luminal $\mathrm{A}_{\mathrm{mRNA}}$ and Luminal $\mathrm{B}_{\mathrm{mRNA}}$ groups into a single group to be compared with the Luminal ${ }_{\text {IHC }}$ group; (3) took the $\mathrm{TN}_{\mathrm{IHC}}$ group as the equivalent of the Basal $\mathrm{m}_{\text {mNA }}$ group and (4) assumed equivalence of the HER2 $+_{\text {IHC }}$ and HER $2+_{\text {mRNA }}$ groups. As shown in Table 2, the IHC and molecular subtypes are highly concordant except for the HER2+ groups. With the HER2+ ${ }_{\text {IHC }}$ group included, the overall concordance is $87 \%$ and the observed unweighted kappa is $74 \%$. Without the HER2+ groups, i.e., removing all samples that were either classified as HER2+ ${ }_{\text {IHC }}$ or as HER $2+_{\text {mRNA }}$, the overall concordance increases to $97 \%$ and an observed unweighted kappa of $97 \%$.

To study the Luminal ${ }_{\mathrm{IHC}}-$ Basal $_{\text {mRNA }}$ mismatches, the ER mRNA expression levels of these samples were estimated based on the microarray hybridizations. Two of the three mismatches had the lowest ER mRNA expression of all Luminal $_{\text {IHC }}$ tumors. One of these also had relatively low ER protein expression by IHC (only $10 \%$ of nuclei) while the other had a high number of nuclei staining positive $(70 \%)$. The third mismatch had both high IHC positivity $(100 \%)$ and average ER mRNA expression. The single $\mathrm{TN}_{\text {IHC}}$-Luminal $\mathrm{A}_{\text {mRNA }}$ mismatch had the highest ER mRNA expression of all $\mathrm{TN}_{\mathrm{IHC}}$ tumors.

Molecular subtype assignments of the HER2 ${ }_{\text {IHC }}$ samples

Of the 43 HER2 $+_{\text {IHC }}$ samples, 7 (16\%) had low HER2 mRNA expressions in the microarray analysis. To resolve this discrepancy, five of these tumors could be retested for HER2 gene amplification by IHC and CISH, and all now tested negative. For the other two samples, no tumor tissue remained from the small pretreatment biopsies. In general, however, HER2 mRNA expression and the level of HER2 positive staining showed a reasonable correlation (Supplemental Fig. 1). The only discordances were the seven samples discussed earlier. The five identified false-positive HER2 $+_{\text {IHC }}$ tumors were excluded from all further analysis.

The remainder of the HER2 $+_{\text {IHC }}$ samples had a moderate to high HER2 mRNA expression (36 of 43) and were scored positive based on IHC. These tumors most likely do have a HER2 gene amplification but were not all classified

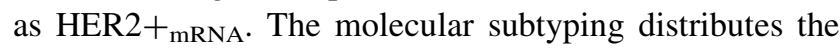
HER2 $+_{\text {IHC }}$ tumors across all molecular subtypes. A significant proportion is classified as Luminal $\mathrm{A}_{\text {mRNA }}$ or as Luminal $B_{\mathrm{mRNA}}$. Since these subtypes are largely characterized by their hormone receptor status, we next subdivided the IHC subtypes according to their hormone receptors (Table 2). All nine HER2 $+_{\mathrm{IHC}} /$ Luminal $\mathrm{A}_{\text {mRNA }}$ and all four HER2 ${ }_{{ }_{I H C}} /$ Luminal $B_{\text {mRNA }}$ had a positive ER by IHC. Two HER $2+_{\text {IHC }} / E R+_{\text {IHC }}$ tumors were classified as Basal $_{\text {mRNA }}$, five as HER $2+_{\text {mRNA }}$ and two as Normallike mRNA. $_{\text {. }}$

Evaluation of the IHC analogs of the Luminal $A_{\text {mRNA }}$ and Luminal $B_{\text {mRNA }}$ subtypes

Since the IHC subtyping only allows for a subdivision into a Luminal $_{\mathrm{IHC}}$, a HER2 ${ }_{\mathrm{IHC}}$ and a $\mathrm{TN}_{\mathrm{IHC}}$ group, it has been reported that PR status can be used to further subdivide the

Table 2 IHC and molecular subtype concordance

\begin{tabular}{llllll}
\hline & Basal $_{\text {mRNA }}$ & HER2 $+_{\text {mRNA }}$ & Luminal $_{\text {mRNA }}$ & Luminal $_{\text {mRNA }}$ & Normal-like $_{\text {mRNA }}$ \\
\hline $\mathrm{TN}_{\mathrm{IHC}}$ & 44 & 1 & 1 & 0 & 2 \\
$\mathrm{HER} 2+/ \mathrm{ER}+{ }_{\mathrm{IHC}}$ & 2 & $6(5)$ & $10(9)$ & $5(4)$ & $3(2)$ \\
HER2+/ER- & $5(4)^{\mathrm{a}}$ & 11 & 0 & 0 & 1 \\
Luminal/PR+ & 2 & 1 & 59 & 14 & 1 \\
Luminal/PR- & 1 & 0 & 14 & 10 & 2 \\
\hline
\end{tabular}

${ }^{a}$ Between brackets the number of samples remaining after removal of the false-positive HER $2+{ }_{\mathrm{IHC}}$ 
Luminal $_{\text {IHC }}$ group into a surrogate Luminal $A_{I H C}$ and Luminal $\mathrm{B}_{\mathrm{IHC}}$ group [9]. The reported method was employed to assign the ER+/PR+/HER2 - ${ }_{\text {IHC }}$ tumors to the Luminal $\mathrm{A}_{\mathrm{IHC}}$ group and the $\mathrm{ER}+/ \mathrm{PR}-/ \mathrm{HER} 2-_{\mathrm{IHC}}$ tumors to the Luminal $\mathrm{B}_{\mathrm{IHC}}$ group (see Table 2). Although there appears to be some association between the IHC groups (Luminal $\mathrm{A}_{\mathrm{IHC}}$ and Luminal $\mathrm{B}_{\mathrm{IHC}}$ ) and the molecular subtypes (Luminal $\mathrm{A}_{\mathrm{mRNA}}$ and Luminal $\mathrm{B}_{\mathrm{mRNA}}$ ), this association is not statistically significant (Fisher exact test; $P=0.054$ ) and the concordance is only $71 \%$ (unweighted kappa $22 \%$ ). Another possibility could be that 'highly endocrine responsive' tumors classify as Luminal $\mathrm{A}_{\mathrm{mRNA}}$ and 'incompletely endocrine responsive' tumors as Luminal $B_{\text {mRNA }}$ [28]. This is, however, not the case (Table 3, Fischer Exact test: $P=0.51$; concordance $46 \%$ ).

HER $2+_{\text {IHC }}$ chemotherapy response by molecular subtype

The full table of response of both breast tumor and axillary lymph nodes by IHC and by molecular subtypes can be found in Supplemental Table I. For the study of response rates, the analysis was limited to those HER $2+{ }_{\mathrm{IHC}}$ tumors that were treated with trastuzumab and chemotherapy. As can be seen from Table 4, the HER2 $+_{\text {IHC }}$ tumors classified as either Luminal $\mathrm{A}_{\mathrm{mRNA}}$ or Luminal $\mathrm{B}_{\mathrm{mRNA}}$ have a much lower pCR rate than the non-Luminal group $(P=0.009$, Fisher exact test; odds ratio: 14.7 [95\% confidence interval: 1.59-135.33]).

Luminal $\mathrm{A}_{\mathrm{mRNA}}$ and Luminal $\mathrm{B}_{\mathrm{mRNA}}$ response rates

Molecular subtyping allows the separation of Luminal tumors into the Luminal $\mathrm{A}_{\mathrm{mRNA}}$ and Luminal $\mathrm{B}_{\mathrm{mRNA}}$ subgroups. One pCR was found in each subgroup (Table 5) resulting in a slightly (and not significantly) higher pCR rate in the Luminal $\mathrm{B}_{\mathrm{mRNA}}$ subgroup $(P=0.44$, Fisher exact test).

Response rates of the primary tumor

The effect of treatment on the breast tumor alone is shown in Table 6, 7. In this overview, the Luminal groups again show a worse response than the non-Luminal groups,
Table 4 Response of HER2+ ${ }_{\text {IHC }}$ tumors to trastuzumab-chemotherapy by molecular subtype

\begin{tabular}{|c|c|c|c|c|}
\hline & No pCR & $\mathrm{pCR}$ & $\mathrm{pCR}$ fraction & $\mathrm{CI}$ \\
\hline Basal $_{\text {mRNA }}$ & 2 & 4 & 0.67 & $0.30-0.90$ \\
\hline HER $2+{ }_{\text {mRNA }}$ & 6 & 7 & 0.54 & $0.29-0.77$ \\
\hline Normal-like $_{\text {mRNA }}$ & 1 & 1 & 0.50 & $0.09-0.91$ \\
\hline Luminal $A_{\text {mRNA }}$ & 8 & 1 & 0.11 & $0.02-0.44$ \\
\hline Luminal $B_{\text {mRNA }}$ & 3 & 0 & 0 & $0.00-0.56$ \\
\hline
\end{tabular}

although more than half of the Luminal tumors are being classified as partial responders.

\section{Discussion}

The relevance of molecular subtyping for breast cancer has achieved widespread acceptance. The designations 'Luminal' and 'Basal' have become part of the standard clinical terminology, although its use is often not based on microarray analysis, but rather on the routinely available tests for the estrogen- and progesterone receptors and for amplification of the HER2 gene. The four-way subtyping in ER+/HER2 - tumors, triple negatives, HER2+/ER+ and HER 2+/ER - tumors must be done when adjuvant or neoadjuvant treatment is considered, since it is indispensable for the selection of drug therapy. Endocrine treatments are only effective in the ER+ tumors, trastuzumab-based treatments only in the HER2 + tumors, while chemotherapy may be beneficial in all groups, particularly in the ERtumors.

Both the clinical and the molecular subtypes have been associated with prognosis and with sensitivity to chemotherapy. For instance, it has been shown that the Luminal $\mathrm{A}_{\text {mRNA }}$ group has a favorable prognosis compared to the other molecular subtypes and that the $\mathrm{Basal}_{\mathrm{mRNA}}$ group has the worst prognosis $[15,18]$. The same is true for the $\mathrm{ER}+{ }_{\mathrm{IHC}} / \mathrm{HER} 2-{ }_{\mathrm{IHC}}$ and the triple negative $\mathrm{IHC}_{\mathrm{IHC}}$ subgroups. In addition, the Basal $_{\text {mRNA }}$ (or triple negative ${ }_{\mathrm{IHC}}$ ) and HER2+ molecular and IHC groups have been shown to be relatively sensitive to $\mathrm{CT}$ while the Luminal molecular and IHC groups are less so [30, 31]. A possible confounder in the response evaluation of our study could be the different regimens of chemotherapy that patients received. However,

Table 3 Endocrine responsiveness index concordance with molecular subtypes

\begin{tabular}{lccccc}
\hline & Basal $_{\text {mRNA }}$ & HER2 $+_{\text {mRNA }}$ & Luminal $_{\text {mRNA }}$ & Luminal $_{\text {mRNA }}$ & Normal-like $_{\text {mRNA }}$ \\
\hline ERI- & 48 & 12 & 1 & 0 & 3 \\
ERI+ & 2 & 4 & 39 & 16 & 2 \\
ERI++ & 3 & 2 & 43 & 12 & 3 \\
\hline
\end{tabular}

Abbreviations: ERI-, endocrine non-responsive; ERI+, incompletely endocrine responsive; ERI++, highly endocrine responsive 
Table 5 CT response rates for Luminal $A_{m R N A}$ and Luminal $B_{m R N A}$ subtypes

\begin{tabular}{lllll}
\hline & No pCR & pCR & pCR fraction & CI \\
\hline Luminal $\mathrm{A}_{\mathrm{mRNA}}$ & 81 & 1 & 0.01 & $0.00-0.07$ \\
Luminal $\mathrm{B}_{\mathrm{mRNA}}$ & 26 & 1 & 0.04 & $0.01-0.18$ \\
\hline
\end{tabular}

Table 6 Response of primary tumor by IHC subtype

\begin{tabular}{lrrll}
\hline & NR & PR & Near-pCR breast & pCR breast \\
\hline TN $_{\text {IHC }}$ & 11 & 17 & 1 & 18 \\
HER2 $_{\text {IHC }}$ & 9 & 6 & 5 & 18 \\
Luminal $_{\text {IHC }}$ & 50 & 41 & 5 & 5 \\
\hline
\end{tabular}

Table 7 Response of primary tumor by molecular subtype

\begin{tabular}{lrrll}
\hline & NR & PR & Near-pCR breast & pCR breast \\
\hline Basal $_{\text {mRNA }}$ & 12 & 15 & 1 & 23 \\
HER2 $+_{\text {mRNA }}$ & 3 & 6 & 1 & 8 \\
Luminal A & 41 & 30 & 5 & 6 \\
Luminal $B_{\text {mRNA }}$ & 10 & 11 & 4 & 2 \\
Normal-like $_{\text {mRNA }}$ & 4 & 2 & 0 & 2 \\
\hline
\end{tabular}

the different regimens are not restricted to or overrepresented in specific subtypes (with the exception of the trastuzumab-based treatment regimen) and since other studies that used the same regimen across all subtypes reported similar results, we consider the overall conclusions to be valid [30, 32]. For the day-to-day management of breast cancer with preoperative chemotherapy, the questions arises whether the additional effort and expense of true molecular subtyping is justified by an improved accuracy of response prediction.

We examined 195 tumor biopsies from breast cancer patients who were scheduled for neoadjuvant chemotherapy, and we classified the tumors according to routine clinical tests for ER and PR protein expression as well as HER2 gene amplification. Using mRNA expression microarrays, we also classified the tumors according to the molecular subtypes that have been derived from unsupervised, hierarchical clustering of primary human breast cancers. The comparison of the two subtyping systems suggests that molecular subtyping will probably not have a major impact on treatment selection for preoperative chemotherapy for most patients with breast cancer. The Luminal and Basal molecular subtypes largely coincide with the clinical subtypes Luminal ${ }_{\mathrm{IHC}}$ $\left(\mathrm{ER}+_{\mathrm{IHC}} / \mathrm{HER} 2-_{\mathrm{IHC}}\right)$ and triple negative ${ }_{\mathrm{IHC}}$. The use of a molecular classification system does not appear to offer a better prediction of neoadjuvant therapy response than a simpler routine IHC/FISH based method. The further subdivision into Luminal $\mathrm{A}_{\mathrm{mRNA}}$ and Luminal $\mathrm{B}_{\mathrm{mRNA}}$ groups is not mirrored by the immunohistochemistry for the Progesterone receptor, nor by the differentiation between 'highly endocrine responsive' and 'incompletely endocrine responsive' tumors. In contrast to what was reported by others [33], we did not observe a significantly better response to $\mathrm{CT}$ in Luminal $\mathrm{B}_{\mathrm{mRNA}}$ tumors in comparison to Luminal $\mathrm{A}_{\mathrm{mRNA}}$ tumors. It should be noted that the sample size could obscure small, but real, differences in response rates. However, the clinical relevance of these small differences is arguable. None of the three approaches to further subdivide the $\mathrm{ER}+_{\mathrm{IHC}} / \mathrm{HER} 2-_{\mathrm{IHC}}$ group appears to result in better predictors of chemotherapy response, despite the fact that the prognostic power of each of these has been well documented [34-39]. Although the Luminal tumors in general do not reach a pCR, a significant proportion (53\%) of these achieve a reduction in primary (breast) tumor volume of at least $50 \%$. Treatment of these tumors with chemotherapy can allow breast-conserving surgery to take place [34-39] and as such can be an effective treatment option for this group. The Normal-like subgroup is so small that no conclusions can be drawn at this moment.

Quite a different situation, however, exists in the group of tumors that harbor a HER2 gene amplification. The concordance between the HER $2+_{\mathrm{IHC}}$ and HER $2+_{\text {mRNA }}$ subtypes is low. A small part of this lack of concordance can be explained by false-positive HER2 IHC staining. This is not unexpected, as several studies have investigated the reproducibility of immunohistochemistry for HER2 protein expression, and poor results with false-positive rates around $10-15 \%$ have been reported $[10,11]$.

The remaining discrepancies are the result of intrinsic differences between the two subtyping methods. Many HER2-amplified tumors are classified as Luminal tumors in the molecular classification (34\%). All HER $2+{ }_{\mathrm{IHC}}$ now routinely receive trastuzumab as part of the (neo)adjuvant regimen and this has proven to be very effective. In our hands, the HER $2+{ }_{\mathrm{IHC}} / \mathrm{ER}-{ }_{\mathrm{IHC}}$ tumors are particularly sensitive to the trastuzumab/paclitaxel/carboplatin (TPC) regimen and achieve a pCR rate of $64 \%$ (Supplemental Table II). The response rate of the molecular HER2 subtype is lower (54\%, Table 4) and does not improve on the clinical response prediction. Interestingly, however, the HER2-amplified tumors that are classified as Luminal by mRNA expression, have a very low pCR rate $(8 \%$, Table 4), which is lower than that of the clinically identifiable HER2+/ER+ group (21\%, Supplemental Table II). In univariate analyses, only the Luminal molecular subtype and ER-status were found to be significant predictors of response (variables tested included: grade $(>2)$, age $(>48)$, tumor size $(>\mathrm{T} 2)$ and lymph node involvement). In a multivariate analysis (logistic regression), the model including ER-status and Luminal molecular subtype was 
better in predicting response than the model with ER-status alone, but not significantly so $(P=0.08$; Supplemental Table III). To perform a conclusive multivariate analysis, more samples will be needed.

Thus, intrinsic resistance of HER2-amplified Luminal ${ }_{\text {mRNA }}$ tumors to trastuzumab-based chemotherapy regimens may exist. Reported mechanisms of resistance to trastuzumab include altered receptor-antibody interaction, signaling by HER receptor family members, IGF1R signaling, modulation of P2 $7^{\mathrm{KIP} 1}$ and loss of PTEN and/or PI3K pathway activation [40, 41]. We observed that the PTEN mRNA expression in the HER $2+_{{ }_{\mathrm{IHC}}}$ Luminal $_{\text {mRNA }}$ group tended to be higher than that in the HER2 ${ }_{\mathrm{IHC}}$ /non-Luminal $_{\text {mRNA }}$ group ( $P=0.06$, Mann-Whitney test), suggesting that PTEN inactivation has no role in this context. The number of tumors in our series is small and a recent, larger study reported more similar response rates for $\mathrm{HER} 2+_{\mathrm{IHC}} /$ $\mathrm{ER}+{ }_{\mathrm{IHC}}$ and $\mathrm{HER} 2+_{\mathrm{IHC}} / \mathrm{ER}-{ }_{\mathrm{IHC}}$ patients to trastuzumabbased treatment (47 vs. 61\%, respectively) than what we have found (21 vs. 64\%) [42]. Although a different treatment regimen was used in that study (trastuzumab with paclitaxel and FEC) and they did not include the molecular classification in their analysis, confirmation of our finding from independent series is required. If confirmed, this finding could lead to an mRNA expression-based test on pretreatment biopsies predictive for tumor unresponsiveness to trastuzumab-based treatment. The efficacy of newer drugs that block the HER2 receptor by other mechanisms than trastuzumab, such as lapatinib, should be explored with priority in these relatively insensitive subgroups.

We conclude that the time has not yet come for the routine use of molecular subtyping in the neoadjuvant treatment setting of breast cancer. In our series of 195 patients, standard subtyping based on ER and PR status and HER2 gene amplification performed as well and remains essential for treatment selection. In the HER $2+_{\mathrm{IHC}}$ subgroup, mRNA expression analysis identified false-positive HER $2_{\mathrm{IHC}}$ results, but these false positives could have been avoided by an in situ hybridization test. A separate group with low responsiveness to trastuzumab-based chemotherapy may be formed by the HER $2+_{\mathrm{IHC}} /$ Luminal $_{\text {mRNA }}$ tumors.

Acknowledgments This study was performed within the framework of CTMM, the Center for Translational Molecular Medicine (www. ctmm.nl), project Breast CARE (grant 03O-104).

\section{References}

1. Rakha EA, Ellis IO (2007) An overview of assessment of prognostic and predictive factors in breast cancer needle core biopsy specimens. J Clin Pathol 60:1300-1306
2. Denley H, Pinder SE, Elston CW, Lee AH, Ellis IO (2001) Preoperative assessment of prognostic factors in breast cancer. $\mathrm{J}$ Clin Pathol 54:20-24

3. Valero V, Buzdar AU, Hortobagyi GN (1996) Locally advanced breast cancer. Oncologist 1:8-17

4. Nicholson RI, Johnston SR (2005) Endocrine therapy-current benefits and limitations. Breast Cancer Res Treat 93(Suppl 1):S3S10

5. Hayashi S, Yamaguchi Y (2008) Estrogen signaling pathway and hormonal therapy. Breast Cancer 15:256-261

6. Tokunaga E, Oki E, Nishida K, Koga T, Egashira A, Morita M et al (2006) Trastuzumab and breast cancer: developments and current status. Int J Clin Oncol 11:199-208

7. Ross JS, Fletcher JA, Bloom KJ, Linette GP, Stec J, Symmans WF et al (2004) Targeted therapy in breast cancer: the HER-2/ neu gene and protein. Mol Cell Proteomics 3:379-398

8. Nielsen DL, Andersson M, Kamby C. (2008) HER2-targeted therapy in breast cancer. Monoclonal antibodies and tyrosine kinase inhibitors. Cancer Treat Rev 35:121-136

9. Nguyen PL, Taghian AG, Katz MS, Niemierko A, Abi Raad RF, Boon WL et al (2008) Breast cancer subtype approximated by estrogen receptor, progesterone receptor, and HER-2 is associated with local and distant recurrence after breast-conserving therapy. J Clin Oncol 26:2373-2378

10. Gown AM (2008) Current issues in ER and HER2 testing by IHC in breast cancer. Mod Pathol 21(Suppl 2):S8-S15

11. Ellis CM, Dyson MJ, Stephenson TJ, Maltby EL (2005) HER2 amplification status in breast cancer: a comparison between immunohistochemical staining and fluorescence in situ hybridisation using manual and automated quantitative image analysis scoring techniques. J Clin Pathol 58:710-714

12. Dowsett M, Hanna WM, Kockx M, Penault-Llorca F, Ruschoff J, Gutjahr T et al (2007) Standardization of HER2 testing: results of an international proficiency-testing ring study. Mod Pathol 20:584-591

13. Sanchez-Munoz A, Garcia-Tapiador AM, Martinez-Ortega E, Duenas-Garcia R, Jaen-Morago A, Ortega-Granados AL et al (2008) Tumour molecular subtyping according to hormone receptors and HER2 status defines different pathological complete response to neoadjuvant chemotherapy in patients with locally advanced breast cancer. Clin Transl Oncol 10:646-653

14. Desmedt C, Haibe-Kains B, Wirapati P, Buyse M, Larsimont D, Bontempi $G$ et al (2008) Biological processes associated with breast cancer clinical outcome depend on the molecular subtypes. Clin Cancer Res 14:5158-5165

15. Perou CM, Sorlie T, Eisen MB, van de Rijn M, Jeffrey SS, Rees CA et al (2000) Molecular portraits of human breast tumours. Nature 406:747-752

16. Sorlie T, Tibshirani R, Parker J, Hastie T, Marron JS, Nobel A et al (2003) Repeated observation of breast tumor subtypes in independent gene expression data sets. Proc Natl Acad Sci U S A 100:8418-8423

17. Sorlie T, Perou CM, Tibshirani R, Aas T, Geisler S, Johnsen H et al (2001) Gene expression patterns of breast carcinomas distinguish tumor subclasses with clinical implications. Proc Natl Acad Sci U S A 98:10869-10874

18. Hu Z, Fan C, Oh DS, Marron JS, He X, Qaqish BF et al (2006) The molecular portraits of breast tumors are conserved across microarray platforms. BMC Genomics 7:96

19. Loo CE, Teertstra HJ, Rodenhuis S, van de Vijver MJ, Hannemann J, Muller SH et al (2008) Dynamic contrast-enhanced MRI for prediction of breast cancer response to neoadjuvant chemotherapy: initial results. AJR Am J Roentgenol 191:1331-1338

20. Chollet P, Amat S, Cure H, de Latour M, le Bouedec G, MouretReynier MA et al (2002) Prognostic significance of a complete 
pathological response after induction chemotherapy in operable breast cancer. Br J Cancer 86:1041-1046

21. Dawood S, Broglio K, Kau SW, Islam R, Symmans WF, Buchholz TA et al (2008) Prognostic value of initial clinical disease stage after achieving pathological complete response. Oncologist 13:6-15

22. Guarneri V, Broglio K, Kau SW, Cristofanilli M, Buzdar AU, Valero V et al (2006) Prognostic value of pathologic complete response after primary chemotherapy in relation to hormone receptor status and other factors. J Clin Oncol 24:1037-1044

23. Kuerer HM, Newman LA, Smith TL, Ames FC, Hunt KK, Dhingra K et al (1999) Clinical course of breast cancer patients with complete pathologic primary tumor and axillary lymph node response to doxorubicin-based neoadjuvant chemotherapy. J Clin Oncol 17:460-469

24. Machiavelli MR, Romero AO, Perez JE, Lacava JA, Dominguez ME, Rodriguez R et al (1998) Prognostic significance of pathological response of primary tumor and metastatic axillary lymph nodes after neoadjuvant chemotherapy for locally advanced breast carcinoma. Cancer J Sci Am 4:125-131

25. Shien T, Shimizu C, Seki K, Shibata T, Hojo T, Ando M et al (2009) Comparison among different classification systems regarding the pathological response of preoperative chemotherapy in relation to the long-term outcome. Breast Cancer Res Treat 113:307-313

26. Hannemann J, Oosterkamp HM, Bosch CA, Velds A, Wessels LF, Loo $\mathrm{C}$ et al (2005) Changes in gene expression associated with response to neoadjuvant chemotherapy in breast cancer. J Clin Oncol 23:3331-3342

27. Ellis IO, Galea M, Broughton N, Locker A, Blamey RW, Elston CW (1992) Pathological prognostic factors in breast cancer. II. Histological type. Relationship with survival in a large study with long-term follow-up. Histopathology 20:479-489

28. Colleoni M, Bagnardi V, Rotmensz N, Gelber RD, Viale G, Pruneri $G$ et al. (2008) Increasing steroid hormone receptors expression defines breast cancer subtypes non responsive to preoperative chemotherapy. Breast Cancer Res Treat 116:359369

29. Cohen J (1960) A Coefficient of Agreement for Nominal Scales. Educ Psychol Measur 20:37-46

30. Goldstein NS, Decker D, Severson D, Schell S, Vicini F, Margolis J et al (2007) Molecular classification system identifies invasive breast carcinoma patients who are most likely and those who are least likely to achieve a complete pathologic response after neoadjuvant chemotherapy. Cancer 110:1687-1696

31. Rouzier R, Perou CM, Symmans WF, Ibrahim N, Cristofanilli M, Anderson $\mathrm{K}$ et al (2005) Breast cancer molecular subtypes respond differently to preoperative chemotherapy. Clin Cancer Res 11:5678-5685

32. Andre F, Mazouni C, Liedtke C, Kau SW, Frye D, Green M et al (2008) HER2 expression and efficacy of preoperative paclitaxel/ FAC chemotherapy in breast cancer. Breast Cancer Res Treat 108:183-190

33. Parker JS, Mullins M, Cheang MC, Leung S, Voduc D, Vickery T et al (2009) Supervised risk predictor of breast cancer based on intrinsic subtypes. J Clin Oncol 27:1160-1167

34. Chen AM, Meric-Bernstam F, Hunt KK, Thames HD, Outlaw ED, Strom EA et al (2005) Breast conservation after neoadjuvant chemotherapy. Cancer 103:689-695

35. Kim R, Osaki A, Toge T (2005) Current and future roles of neoadjuvant chemotherapy in operable breast cancer. Clin Breast Cancer 6:223-232

36. Peintinger F, Symmans WF, Gonzalez-Angulo AM, Boughey JC, Buzdar AU, Yu TK et al (2006) The safety of breast-conserving surgery in patients who achieve a complete pathologic response after neoadjuvant chemotherapy. Cancer 107:1248-1254

37. Shimizu C, Ando M, Kouno T, Katsumata N, Fujiwara Y (2007) Current trends and controversies over pre-operative chemotherapy for women with operable breast cancer. Jpn J Clin Oncol 37: $1-8$

38. Straver ME, van Adrichem JC, Rutgers EJ, Rodenhuis S, Linn SC, Loo CE et al (2008) [Neoadjuvant systemic therapy in patients with operable primary breast cancer: more benefits than breast-conserving therapy]Neoadjuvante systemische therapie bij het primair operabel mammacarcinoom: meer voordelen dan alleen borstsparende behandeling. Ned Tijdschr Geneeskd 152: $2519-2525$

39. Thomas A, Ohlinger R, Hauschild M, Mustea A, Blohmer JU, Kummel S (2006) Options and limits of surgery after pre-operative chemotherapy in breast cancer. Anticancer Res 26:16771682

40. Nahta R, Yu D, Hung MC, Hortobagyi GN, Esteva FJ (2006) Mechanisms of disease: understanding resistance to HER2-targeted therapy in human breast cancer. Nat Clin Pract Oncol 3:269-280

41. Berns K, Horlings HM, Hennessy BT, Madiredjo M, Hijmans EM, Beelen K et al (2007) A functional genetic approach identifies the PI3K pathway as a major determinant of trastuzumab resistance in breast cancer. Cancer Cell 12:395-402

42. Peintinger F, Buzdar AU, Kuerer HM, Mejia JA, Hatzis C, Gonzalez-Angulo AM et al (2008) Hormone receptor status and pathologic response of HER2-positive breast cancer treated with neoadjuvant chemotherapy and trastuzumab. Ann Oncol 19: $2020-2025$ 